УДК 811.111 '42

DOI https://doi.org/10.26661/2414-1135-2021-83-27

\title{
НОМІНАЦІЯ ПОДЯКИ В АВТОРСЬКОМУ КОМЕНТАРІ ТА ПЕРСОНАЖНОМУ МОВЛЕННІ
}

\author{
Москалюк О. В. \\ кандидат педагогічних наук, доцент, \\ дочент кафедри філології \\ Одеський національний морський університет \\ вул. Мечникова, 34, Одеса, Україна \\ orcid.org/0000-0003-4956-7238 \\ moskalyukev@gmail.com \\ Ківенко І. О. \\ кандидат філологічних наук, \\ дочент кафедри філології \\ Одеський національний морський університет \\ вул. Мечникова, 34, Одеса, Україна \\ orcid.org/0000-0003-2044-5456 \\ innakivenko@gmail.com
}

Ключові слова: авторський коментар, внутрішне мовлення, мовленнєвий акт, невласне пряма мова, передоручена розповідь, персонажне мовлення, подяка.
У статті представлене дослідження лінгвальних засобів номінації подяки в авторському коментарі та персонажному мовленні. Авторський коментар являє собою особливий функціональний модуль, що $\epsilon$ невід'ємною частиною художнього твору. Він нерозривно пов'язаний iз діалогом персонажів, містить уточнення й пояснення дат / імен / подій, відображення екстралінгвальних особливостей спілкування й опис вживаних персонажами невербальних комунікативних засобів, що спрямовано на включеність читача у твір. Персонажне мовлення може бути діалогічним та внутрішнім. Останнє зосереджує в собі мотиви подій, розкриває їхні причинно-наслідкові зв'язки та справжні відношення, експлікуючи їхню сутність. Лінгвальний інвентар номінації подяки в авторському коментарі та персонажному мовленні доволі скромний. Найуживанішим лінгвальним засобом номінації подяки $\epsilon$ прикметник grateful $(42,4 \%)$, який описує внутрішній стан персонажа. Зазвичай він має місце у висловлюванні feel grateful й може бути посилений прислівниками really, so, modestly, gaspingly. Майже в два рази рідше зустрічається дієслово to thank (23,5\%). Ступінь щирості подяки, реалізованої to thank, детермінується прислівниками merely / silently / profusely. Ще рідше вживається іменник gratitude (12,9\%) y виразах feel gratitude, smile with gratitude, take with gratitude, hug in gratitude. Прислівник gratefully $(8,2 \%)$ комбінується 3 дієсловами murmur, hug, smile, clasp. Найменш уживаними лінгвальними засобами номінації подяки в авторському коментарі та персонажному мовленні $\epsilon$ віддієслівний іменник thanks, що трапляється 3 дієсловами grunt та murmur й у сталому виразі smile one's thanks, thank-you, $i$ to appreciate, та їхні похідні appreciatively й thankful. Їхня частка становить від $1,2 \%$ до 2,4\%. Серед інших лінгвальних засобів номінації подяки в авторському коментарі та персонажному мовленні зафіксовані дієслова, що позначають тактильність. 


\title{
NOMINATION OF GRATITUDE IN AUTHOR'S COMMENTARY AND PERSONNAGE'S SPEECH
}

\author{
Moskaliuk O. V. \\ Candidate of Pedagogical Sciences, Associate Professor, \\ Associate Professor at the Department of Philology \\ Odessa National Maritime University \\ Mechnykova str., 34, Odesa, Ukraine \\ orcid.org/0000-0003-4956-7238 \\ moskalyukev@gmail.com \\ Kivenko I. O. \\ Candidate of Philological Sciences, \\ Associate Professor at the Department of Philology \\ Odessa National Maritime University \\ Mechnykova str., 34, Odesa, Ukraine \\ orcid.org/0000-0003-2044-5456 \\ innakivenko@gmail.com
}

Key words: author's commentary, entrusted narrative, gratitude, interior speech, personage's speech, represented speech, speech act.

\begin{abstract}
The given article presents the research of lingual means of gratitude nomination in author's commentary and personage's speech. Author's commentary is a special functional module that makes up an integral part of the fiction. It is inseparably linked to the personages' dialogue as it contains specification and explanation of dates / names / events, reflects extralinguistic peculiarities of communication and depicts non-verbal communicative means, used by speakers, which is aimed at involving the reader into the text. Personage's speech can be uttered (or dialogue) and interior. The latter includes the reasons for certain events, reveals their cause-effect relations as well as the real ones explicating their essence. The lingual inventory of gratitude nomination in author's commentary and personage's speech is quite modest. The most frequently used lingual means of gratitude nomination is the adjective grateful (42.4\%), which describes the personage's inner state. As a rule, it occurs in the expression feel grateful and can be intensified with such adverbs as really, so, modestly, gaspingly. In almost half as many samples we encounter the verb to thank $(23.5 \%)$. The degree of gratitude sincerity, realized by means of to thank, is determined by the adverbs merely / silently / profusely. Even more rarely we observe the noun gratitude (12.9\%) that occurs in such combinations as feel gratitude, smile with gratitude, take with gratitude, hug in gratitude. The adverb gratefully $(8.2 \%)$ is usually combined with the verbs murmur, hug, smile, clasp. The least used lingual means of gratitude nomination in author's commentary and personage's speech include: the verbal noun thanks that goes in pair with the verbs grunt and murmur as well as in the set expression smile one's thanks, thank-you and to appreciate and their derivatives - appreciatively and thankful. They all make up from $1.2 \%$ to $2.4 \%$ of the material analysed. The verbs denoting tactile perception are among other lingual means of gratitude nomination in author's commentary and personage's speech as well.
\end{abstract}

Постановка проблеми. Представлене дослідження $є$ спробою описати лінгвальні засоби номінації подяки в авторському коментарі та персонажному мовленні в англомовному дискурсі.
Вважаємо подяку мовленнєвим актом (далі МА), що відіграє важливу роль у підтримці ввічливих відносин між співрозмовниками та забезпеченні гармонійної комунікації. МА подяки слугує засобом прояву взаємної поваги та уваги до оточуючих. 
Відсутність практики комплексного опису лінгвальних засобів номінації подяки в авторському коментарі та персонажному мовленні в англомовному дискурсі зумовлює актуальність нашого дослідження.

Зауважимо, що, як правило, лінгвісти розглядають МА подяки як одиницю мовленнєвого етикету, що слугує для реалізації певних комунікативних функцій [1-12], описують контексти функціонування подяки [13-15], вивчають подяку як мовленнєву тактику [16], аналізують структури мовленнєвих епізодів, до складу яких входить МА подяки $[15 ; 17 ; 18]$, фрагментарно описують інтонацію подяки [19]. В нашому дослідженні увага зосереджена на вивченні лінгвальних засобів номінації подяки в авторському коментарі та персонажному мовленні в англомовному дискурсі.

Мета і завдання статті. Mema роботи полягає в диференціації лінгвальних засобів, що номінують подяку в авторському коментарі та персонажному мовленні в англомовному художньому дискурсі.

3 поставленої мети витікають такі завдання:

- вивчити способи викладу художнього твору;

- проаналізувати поняття авторський коменmap;

- описати поняття невласне пряме мовлення персонажів; вidi;

- окреслити особливості передорученої розпо-

- проаналізувати лінгвальні засоби номінації подяки в авторському коментарі та персонажному мовленні.

Матеріалом дослідження послугували 192 мовленнєвих епізоди 3 МА подяки, відібрані методом суцільної вибірки із сучасних англомовних художніх творів.

Предмет та об'єкт дослідження. Об’єктом нашого дослідження вибрано МА подяки. Предметом вивчення слугують лінгвальні засоби вираження подяки в авторському коментарі та персонажному мовленні в англомовному дискурсі.

Виклад основного матеріалу дослідження. Нашу наукову розвідку розпочато 3 вивчення способів викладу художнього твору. На думку В.А. Кухаренко, існує два головних мовленнєвих потоки художнього тексту: авторський та персонажний. Останній є неоднорідним: про що герой говорить, висловлюючи свої судження в зовнішньому діалогічному мовленні, що звучить, про що він думає, не проговорюючи свої думки вголос. У творі вони виражені у формі внутрішнього мовлення. Виділяють також й контамінований, змішаний виклад, в якому присутні і герой, і автор, що становить невласне пряме мовлення [20, с. 68].

Спочатку проаналізуємо поняття «авторський коментар»».
Авторський коментар як невід'ємна частина художнього твору являє собою особливий функціональний модуль, комунікативні характеристики якого відрізняються від діалогу персонажів та від авторської розповіді через те, що саме авторський коментар забезпечує зв'язок між діалогом та авторською розповіддю. Аналіз літератури, присвяченої вивченню авторського коментаря, показує, що ця частина художнього твору мало досліджена в плані жанрової специфіки. Уживані терміни, такі як «авторське введення конструкцій прямої мови» [21; 22], «слова автора», що використовується в граматиці як протиставлення «прямій мові», «ремарка», яка позначає те саме в драматургії, не розкривають повною мірою особливостей тієї частини художнього твору, де автор описує різноманітні особливості комунікативної ситуації. Саме тому вслід за О.В. Щелкуновою ми звертаємося до поняття «авторський коментар» [23].

Словникова дефініція коментаря передбачає «роз'яснювальні примітки до якого-небудь тексту; пояснювальні міркування та критичні зауваження про що-небудь» [24, с. 385]. Іншими словами, коментар передбачає наявність чогось, що потребує пояснення, наприклад, дати, імен, згадування певних подій тощо. У нашому дослідженні під «чимось», що потребує пояснення, розуміється комунікативна ситуація, описувана автором. Слід зауважити, що в межах проведеного дослідження авторський коментар стосується комунікації персонажів. У художньому творі до читача доходить мовлення персонажів, але повна картина комунікативної ситуації недоступна, тому авторський коментар спрямовано на те, щоб донести до читача відсутні деталі ситуації спілкування. Ці деталі допомагають краще зрозуміти репліки персонажів. Таким чином, об'єктом авторського коментаря $€$ описувана автором комунікативна ситуація, показником наявності якої в тексті $\epsilon$ частіш за все пряма мова персонажів. При цьому авторський коментар розташовано в безпосередній близькості до прямої мови, однак необов'язково є частиною єдиного 3 нею складного речення $[23$, c. 8$]$.

Нерозривний зв'язок авторського коментаря 3 діалогом персонажів, уточнення й пояснення дат / імен / подій, відображення екстралінгвальних особливостей спілкування й опис вживаних персонажами невербальних комунікативних засобів - все це спрямовано на те, щоб викликати в читача відчуття включеності у твір.

У вітчизняному мовознавстві $є$ термін авторськi кваліфікатори, тобто такі фрагменти художнього твору, що вербалізують паралінгвістичні засоби спілкування персонажів [25]. На відміну від авторського коментаря, спрямованого на уточнення/ пояснення ситуації спілкування, авторські кваліфі- 
катори зосереджують увагу саме на інтонаційних особливостях комунікації та кинесиці, що дещо звужує це поняття. Тому в нашому дослідженні ми оперуємо поняттям авторський коментар.

Далі розглянемо мовлення персонажів та способи його викладення в тексті художнього твору. Персонажне мовлення може бути діалогічним та внутрішнім. Внутрішнє мовлення входить до твору як складник мовленнєвої партії персонажа наряду $з$ діалогічним мовленням. Слід зауважити, що діалогічне мовлення відіграє істотну роль у розвитку сюжету, тоді як внутрішнє мовлення безпосередньої участі в розвитку подій не бере, але зосереджує в собі їхні мотиви, розкриває їхні причинно-наслідкові зв'язки та справжні відношення, експлікуючи їхню сутність [20, с. 135].

У нашому дослідженні увагу зосереджено саме на внутрішньому мовленні персонажів.

Як правило, внутрішнє персонажне мовлення вводиться за допомогою непрямої мови, що являє собою спосіб уведення в текст, до авторської мови чужих висловлень у процесі збереження їхньої змістовної відповідності. На відміну від прямої мови як точно відтвореного чужого висловлення, непряма мова може описати чужий вислів іншими словами, перифрастично, узагальнено, вона позбавлена експресивності й емоційності. Виокремлюють ще невласне пряму мову, яка передбачає введення чужої мови до авторської із збереженням емоційності й експресивності, властивих прямій мові, і є ілюстрацією текстового синкретизму $[25$, c. 418$]$.

Своєю чергою невласне пряма мова є стилістичним прийомом, спрямованим на розкриття внутрішнього світу героя, його думок, почуттів, переживань, що характеризується введенням елементів прямої мови як точно відтворених чужих висловлень до авторської мови в процесі збереження порядку слів, інтонації, емоційності й експресивності прямої мови. Невласне пряма мова не має властивої прямій мові пунктуації. Вона може поєднуватися 3 авторською та прямою мовою, створюючи ефект ототожнення автора-функції й персонажів. У лінгвістиці тексту й стилістиці невласне пряма мова кваліфікується як внутрішнє мовлення, а в лінгвопрагматиці розглядається як комунікативна стратегія перемикання кодів мовлення й мовця. Невласне пряма мова є виявом синтаксичного та текстового синкретизму [там само, c. 412]. На відміну від авторського коментаря, в якому, як правило, пояснюються деталі комунікативної ситуації, невласне пряме мовлення розкриває внутрішній світ головного героя твору.

Номінація подяки має місце і в передорученій розповіді, тобто тоді, коли розповідь ведеться від 1-ої особи. Таким чином, автор передоручає розповідь видуманій особі, переводить сприйняття та освоєння зображуваної дійсності в чужу свідомість, чужу систему правил й оцінок із метою досягнення більшої вірогідності отримуваного зображення. При цьому оповідача включено до художнього світу твору як невід'ємну складову частину, на відміну від власне автора, що завжди займає позицію над персонажами створеного ним світу. Розповідь від 1-ої особи надає твору особливу довіру й інтимність: оповідач впускає читача до свого внутрішнього світу [20, с. 148].

Аналіз відібраних текстових епізодів показує, що МА подяки має місце в усіх описаних способах викладу твору, тобто й в авторському коментарі, й у внутрішньому та невласне прямому мовленні персонажів, і в передорученій розповіді.

Далі розглянемо лінгвальні засоби номінації подяки в авторському коментарі та персонажному мовленні.

На відміну від діалогічного мовлення, в якому кількісно переважає дієслово to thank (93\%) $[27$, с. $115 ; 28$, с. 158$]$, в авторському коментарі та персонажному мовленні в основному вживається прикметник grateful, зафіксований у 42,4\% випадках. Як правило, він має місце у висловлюванні feel grateful, функціонуючи як іменна частина дієслівного присудка й дозволяючи авторові описати подяку, яку відчуває його персонаж. Сам прикметник grateful може бути інтенсифіковано прислівниками really чи so, які наголошують на щирості подяки персонажа. У наведеному прикладі головний персонаж занурює у спогади про свою померлу подругу Рут й відчуває щиру подяку (feel really grateful) за той час, який вони провели разом перед смертю Рут:

When I think about Ruth now, of course, I feel sad she's gone; but I also feel really grateful for that period we had at the end [29, c. 231].

У наступному епізоді щира подяка викликана гарною сукнею, яку молодий чоловік вибирає для своєї нареченої на вечірку, адже він знає, що цей захід збирається відвідати його колишня дівчина. Подяка реалізована висловом feel grateful, в якому прикметник grateful інтенсифіковано прислівником so:

And for a moment, I have never felt so grateful for the dress Christian has given me [30, c. 134].

Окрім really чи so, прикметник grateful може бути посилено іншими прислівниками, а саме gaspingly та modestly, які надають читачеві додаткову інформацію про вирій емоцій та почуттів, що супроводжують подяку. Проілюструємо прикладами: в першому (1) - молода мама у відчаї, адже неочікувано іiі син захворів, однак, незважаючи на сильне хвилювання, вона вдячна (gaspingly grate$f u l)$ своїй подрузі, яка не розгубилася й миттю вжила певних заходіч; в другому (2) - сором'язлива подяка (modestly grateful) заповнює незручну паузу між молодими людьми: 
1. "Where's the patient?" Armed with a fullblown medical kit more suited to an Afghanfield she rushes straight upstairs to Danny's room, leaving me gaspingly grateful for her extraordinary competence $[31$, c. 332].

2. "What is her name?"

"Lalage." < .. > "I know it is strange. " <.. >

"It is Greek. From lalageo, to babble like a brook".

Sarah bowed her head, as if modestly grateful for this etymological information [32, c. 437].

Прикметник grateful функціонує як означення перед іменниками eagerness та tears, тим самим наголошуючи на щирості подяки та емоційній єдності, що виникає між комунікантами. Так, у наступному прикладі Кеті кличе свого друга Тома для розмови, і він, незважаючи на розваги, йде до неї. При цьому хлопець розуміє, що йдеться про щось серйозне. Так, між друзями було заведено ще за часів навчання в інтернаті, коли Кеті виручала хлопця 3 різних халеп, за що Томмі був їй вдячний. Томмі завжди готовий вислухати подругу із вдячливим завзяттям, just a kind of grateful eagerness, що й змусило Кеті пригадати своє минуле:

"Tommy, let's talk now. There's something I want to talk to you about".

As soon as I said this, he let the ball roll away and came to sit down beside me. It was typical of Tommy that once he knew I was willing to talk, there was suddenly no trace left of any sulkiness; just a kind of grateful eagerness that reminded me of the way we were back in the Juniors when a guardian who'd been telling us off went back to being normal [29, c. 103].

В іншому прикладі Бекі настільки розчулилася через слова організатора свого весілля, що не втрималася від сліз подяки, grateful tears, адже тільки ця людина вважає, що дівчина бездоганно спланувала найочікуванішу подію свого життя:

"Well done, Becky".

As she walks away, I feel my eyes pricking with grateful tears. Someone doesn't think I'm a disaster. Someone doesn't think I've ruined everything. In one area, at least, I'm a success [33, c. 321].

Серед сталих виразів у нашій вибірці зафіксовано make / leave smb. grateful та shoot / dart a grateful smile, в якому прикметник grateful $\mathrm{\epsilon}$ означенням іменника smile, що проілюстровано такими прикладами:

1. It's chilling and makes me grateful that Christian is taking me somewhere else [30, c. 179].

2. I dart a grateful smile at her [34, c. 291].

Дієслово to thank, вживане переважно у простому минулому часі, зафіксоване у $23,5 \%$ проаналізованого матеріалу. Також to thank може функціонувати як інфінітив та утворювати дієприкметниковий зворот, який, як правило, експлікує причини, що передували подяці. Ступінь щирості подяки детермінується прислівниками образу дії - merely / silently / profusely, тобто просто / тихенько / дуже відповідно. У наступному прикладі подяка, номінована дієсловом to thank в простому минулому часі, супроводжується тактильністю (squeezed one of her hands in both mine), що наголошує на ії щирості і свідчить про інтимну близькість й емоційний зв'язок між персонажами:

I squeezed one of her hands in both mine when I thanked her [29, c. 75].

В іншому прикладі жінка вдячна сусіду за допомогу 3 ремонтом, адже іiі власний чоловік загинув на війні. Щирість їі подяки не викликає сумніву: на знак подяки й високої оцінки помочі вона власноруч спекла сусідові хліб:

His neighbour, Martha Shaw, was there to thank him, bringing three loaves of homemade bread in appreciation for what he'd done $<\ldots>$ he'd spent a few days at her place last week repairing her roof, replacing broken windows and sealing the others, and fixing her wood stove [35, c. 31-32].

У $12,9 \%$ проаналізованих текстових уривків спостерігається вживання абстрактного іменника gratitude, що безпосередньо номінує подяку. Згідно 3 нашими спостереженнями, в авторському коментарі та персонажному мовленні gratitude комбінується 3 низкою дієслів, а саме feel gratitude, smile with gratitude, take with gratitude, hug in gratitude, що позначають внутрішній стан персонажа, передають його позитивний настрій та прагнення в будьякий спосіб повернути «борг» адресатові подяки. Так, наприклад, Кейт вдячна своїй подрузі за турботу під час хвороби. Подруга приготувала їй суп перед роботою, а коли повернулася, поцікавилася iii станом. Кейт не лише тільки позитивно оцінила кулінарні здібності подруги (it was delicious), а й посмішкою подякувала за страву:

"You look better. Did you eat your soup?" I ask, keen to change the subject.

"Yes, and it was delicious as usual. I'm feeling much better." She smiles at me in gratitude [36, c. 19].

Також було зафіксовано вживання gratitude у словосполученні tears of gratitude як прояв щирої подяки, а також як емоційне вивільнення, що продемонстровано в такому епізоді: дівчина дізнається про те, що ії хлопець потрапляє в авіакатастрофу. На щастя, він неушкодженим повертається додому. Коли вона обіймає його, iіi емоційна напруга спадає. Дівчину охоплюють сльози подяки вищим силам за те, що іiі кохана людина залишилася живою:

I start to relax, resting my head against his chest. He smells outdoorsy, slightly sweaty, of body wash, and Christian, the most welcome scent in the world. Tears start to trickle down my face again, tears of gratitude [30, c. 462].

Прислівник gratefully, або вдячно, з вдячністю, має місце в $8,2 \%$ досліджуваного матеріалу. За 
нашими спостереженнями, він вживається 3 дієсловами murmur, hug, smile, clasp, що можна проілюструвати таким прикладом: Харрі - батько-одинак, він робить все можливе, щоб замінити маленькому сину матір, хоч і не завжди в нього це виходить. Щоб підбадьорити себе, він питає в сина, чи дійсно в них все гаразд без мами. Малий втомлено посміхається батькові й каже, що в них все добре. Харрі цілує сина на добраніч й вдячно обіймає його. Слова хлопця - це те, що чоловік хоче чути в цю мить. Його почуття вдячності щире, чим продиктована тактильність - поцілунок та обійми:

"We're managing without Mummy, aren't we, Pat?" < ... >

Ifelt bad about pushing him like this. But I needed him to tell me that we were doing all right. I needed to know that we were coping. He gave me a tired smile.

"Yes, we 're all right, Daddy," he said, and I kissed him goodnight, hugging him gratefully [37, c. 181]. Зазвичай gratefully експлікує подяку в авторському коментарі / персонажному мовленні, як у прикладі вище, але також може посилювати вже вербалізовану в передуючій репліці мовця подяку, що представлено в такому уривку: Беккі необхідно підняти невеличку тумбочку у квартиру. Таксист виходить із машини, щоб допомогти їй. Беккі вдячна йому за це, про що свідчить їі репліка, іллокутивна сила якої інтенсифікована прислівником gratefully:

"Oh, thanks," I say gratefully. "I could do with some help..." [33, c. 14-15].

Віддієслівний іменник thanks зафіксовано у 3,5\% вибірки у комбінації з дієсловами, що позначають голосові трансформації, - grunt та murmur, а також у сталому виразі smile one's thanks (виразити подяку посмішкою). Наведемо приклади:

1. He then handed the other flute to Jack, who murmured his thanks [38, c. 276].

2. From the street I watched Cyd placing two steaming plates of what looked like Malaysian king prawn curry in front of a pair of young women who smiled their thanks at her [37, c. 309].

Thank-you становить 2,4\% досліджуваного матеріалу. В авторському коментарі та персонажному мовленні thank-you функціонує як іменник та як прикметник, що наведено в прикладах:

1. Andy sent her daughter a silent thank-you [39, с. 388] (іменник).

2. He shoveled a large bite into his mouth and gave Andy a chocolatey thank-you grin [там само, c. 129] (прикметник).

Так само як і thank-you, дієслово to appreciate становить 2,4\% вибірки. Це дієслово не лише номінує подяку, а й водночас експлікує високу оцінку дій адресата подяки.

Похідний прислівник appreciatively становить 1,2\% й має місце в ситуації, коли адресант подяки цінує наміри / дії адресата, але між ними немає емоційної близькості й підкреслюється певна дистанція: Кейт повідомляє подрузі, що їхній новий знайомий допоможе їм переїхати до нового житла. Подруга позитивно оцінює його намір, хоча іiі це дещо насторожує через те, що познайомилися вони зовсім недавно:

"He's going to help us move." < .. >

"That's helpful of him," I say appreciatively [36, с. 160].

Прикметник thankful також становить 1,2\% вибірки. На відміну від appreciatively, він допомагає протагоністу описати власні почуття:

The people here take care of everything. They are good for me, and I'm thankful [35, c. 194].

Інші лінгвальні засоби номінації подяки в авторському коментарі та персонажному мовленні становлять 4,7\%. Переважно зафіксовані дієслова, що позначають тактильність (дотик та поцілунок), як наведено в наступному уривку: Чарльз дарує Сарі колись загублену нею річ. Жінка настільки рада отримати свою прикрасу, що подяка переповнює іii: на її очах з'являються сльози, вона цілує чоловіка й пригортається до нього. Така лексика наголошує на ніжній прив'язаності комунікантів один до одного й емоційній близькості між ними:

Shyly she pressed the little clasp back and opened the box; on a bed of crimson velvet lay an elegant Swiss brooch $<\ldots>$ She looked dewily at Charles. He helpfully closed his eyes. She turned and leaned and planted a chaste kiss softly on his lips; then lay with her head on his shoulder, and looked again at the brooch, and kissed that [32, c. 324].

Висновки і перспективи подальших розробок у цьому напрямі. Проведене дослідження показує, що найуживанішим лінгвальним засобом номінації подяки в авторському коментарі та персонажному мовленні є прикметник grateful $(42,4 \%)$, який описує внутрішній стан персонажа. Як правило, він має місце у висловлюванні feel grateful й може бути посилений такими прислівниками як really, so, modestly, gaspingly. Дієслово to thank зафіксовано у 23,5\% проаналізованого матеріалу. Иого ступінь щирості детермінується прислівниками образу діï - merely / silently / profusely. У 12,9\% досліджених текстових уривків спостерігається вживання абстрактного іменника gratitude у виразах feel gratitude, smile with gratitude, take with gratitude, hug in gratitude. Прислівник gratefully має місце в 8,2\% досліджуваного матеріалу в комбінації з дієсловами murmur, hug, smile, clasp. Зазвичай gratefully експлікує подяку в авторському коментарі / персонажному мовленні або посилює вже вербалізовану в передуючій репліці мовця подяку. Віддієслівний іменник thanks трапляється у 3,5\% вибірки 3 дієсловами, 
що позначають голосові трансформації, - grunt та murmur, а також у сталому виразі smile one's thanks. Thank-you та to appreciate становлять по 2,4\% вибірки кожен, їхні похідні appreciatively та thankful- по 1,2\% кожен. Серед інших лінгвальних засобів номінації подяки в авторському коментарі та персонажному мовленні зафіксовані дієслова, що позначають тактильність. Вони становлять 4,7\% матеріалу.

Перспективою нашого дослідження вважаємо вивчення невербальних засобів вираження подяки в англомовному художньому дискурсі.

\section{ЛІТЕРАТУРА}

1. Остин Дж. Слово как действие. Новое в зарубежной лингвистике. Теория речевых актов. 1986. Вып. 17. С. 22-129.

2. Leech G. Principles of Pragmatics. London : Routledge, 2016. 264 p.

3. Wunderlich D. Methodological remarks on speech act theory. Speech Act Theory and Pragmatics. Holland, 1980. P. 291-312.

4. Ballmer Th., Brennenstuhl W. Speech Act Classification. Berlin : Mouton de Gruyter, 1981. 274 p.

5. Арутюнова Н.Д. Предложение и его смысл. Логико-семантические проблемы. Москва : Наука, 1976. 384 с.

6. Возиянова Н.В. Семантическая структура и текстовые функции глаголов речи : автореф. дис. ... канд. филол. наук : 10.02.19. Москва, 1991. 26 c.

7. Гольдин В.Е. Речь и этикет. Москва : Просвещение, 1983. 109 с.

8. Демьянков В.3. Англо-русские термины по прикладной лингвистике и автоматической переработке текста. Тетради новых терминов. 1982. № 39. С. 159-195.

9. Жумагулова Б.С. Категория контактности между партнерами коммуникации : автореф. дис. ... канд. филол. наук : 10.02.04. Москва, 1987. 23 c.

10. Карасик В.И. Язык социального статуса. Москва : ИТДГК, «Гнозис», 2002. 333 с.

11. Ларина Т.В. Категория вежливости и стиль коммуникации. Сопоставление английских и русских лингвокультурных традиций. Москва : Рукописные памятники Древней Руси, 2009. 507 с.

12. Романов А.А. Прагматические особенности перформативных высказываний. Прагматика и семантика синтаксических единиц. Калинин, 1984. С. 86-92.

13. Адамакова Э.Б. Семантико-прагматические свойства и контексты функционирования средств выражения благодарности в немецком языке : дис. ... канд. филол. наук : 10.02.04 /
Пятигорский государственный лингвистический университет. Пятигорск, 2005. 172 с.

14. Тягунова Ж.А. Контексты функционирования и семантика выражений Thank you и Thanks (когнитивно-прагматический подход) : дис. ... канд. филол. наук : 10.02.04 / Пятигорский государственный лингвистический университет. Пятигорск, 2002. 169 с.

15. Сковородина С.В. Прагматика реактивных речевых актов в немецком диалогическом дискурсе (концепты «благодарность» и «извинение») : дис. ... канд. филол. наук : 10.02.04 / Российский государственный педагогический университет им. А.И. Герцена. Санкт-Петербург, 2004. 219 c.

16. Brown P., Levinson S. Politeness : Universals in Language Usage. Cambridge : Cambridge University Press, 1987. 345 p.

17. Трофимова Н.А. От любви до ненависти. Смысловые узоры экспрессивов. Санкт-Петербург : ИВЭСЭП, 2011. 395 с.

18. Цурикова Л.В. Дискурсивное событие выражения благодарности в английском и русском языках. Kalbu Studijos: Studies about Languages. 2008. № 13. C. 60-70.

19. Aijmer K. Conversational Routines in English: Convention and Creativity. London : Longman Group, 1996. 251 p.

20. Кухаренко В.А. Интерпретация текста : учебник. Москва : ФЛИНТА, 2019. 316 с.

21. Чумаков Г.М. Система вводов прямой речи, их функции и стилистическое использование. Научные доклады высшей школь. Филологические науки. 1972. № 2. С. 76-88.

22. Воронин А.А. Информативный потенциал авторских вводов конструкций прямой речи (на материале романов Дж. Голсуорси) : дис. ... канд. филол. наук : 10.02.04 / Московский государственный лингвистический университет. Москва, 2004. 178 с.

23. Щелкунова О.В. Функционирование средств номинации зрительного восприятия в авторском комментарии (на материале русского и английского языков) : автореф. дис. ... канд. филол. наук : 10.02.01, 10.02.19. Орёл, 2009. 23 с.

24. Ожегов С.И. Словарь русского языка: Ок. 57000 слов / под ред. Н.Ю. Шведовой. Москва : Русский язык, 1984. 797 с.

25. Селиванова Е.А. Основы лингвистической теории текста и коммуникации : монографическое учебное пособие. Киев : ЦУЛ, «Фитосоциоцентр», 2002. 336 с.

26. Селіванова О.О. Сучасна лінгвістика. Термінологічна енциклопедія. Полтава : Довкілля-К, 2006. 716 с.

27. Ківенко I.О. Мовленнєвий акт подяки: прагмалінгвістичний аналіз (на матеріалі англійської 
мови) : дис. ... канд. філол. наук : 10.02.04 / Одеський національний університет ім. I.I. Мечникова. Одеса, 2018. 226 с.

28. Ківенко I.О. Рівневі характеристики МА вдячності в англомовному художньому дискурсі. Науковий вісник Херсонського державного університету. Серія «Лінгвістика». 2013. № 19 . C. $156-159$.

29. Ishiguro K. Never Let Me Go. London : Faber and Faber, 2005. 282 p.

30. James E. L. Fifty Shades Darker. London : Arrow Books, 2012. 532 p.

31. Williams P. How to be Married. London : Headline Publishing Group, 2010. 376 p.

32. Fowles J. The French Lieutenant's Woman. London : Vintage, 2005. $445 \mathrm{p}$.

33. Kinsella S. Shopaholic Ties the Knot. London : Black Swan, 2002. 395 p.

34. Kinsella S. Shopaholic and Sister. London : Black Swan, 2004. 382 p.

35. Sparks N. The Notebook. London : Sphere, 2007. $221 \mathrm{p}$.

36. James E.L. Fifty Shades of Grey. London : Arrow Books, 2012. 514 p.

37. Parsons T. Man and Boy. London : Harper Collins Publishers, 1999. 343 p.

38. Bradford B.T. Playing the Game. London : Harper, 2011. 472 p.

39. Weisberger L. Revenge Wears Prada : The Devil Returns. London : Harper, 2013. 417 p.

\section{REFERENCES}

1. Ostin Dzh. (1986) Slovo kak dejstvie [How to do things with words?]. Novoe vzarubezhnoj lingvistike. Teorija rechevyh aktov, vol. 17, pp. 22-129.

2. Leech G. (2016) Principles of Pragmatics. London : Routledge.

3. Wunderlich D. (1980) Methodological remarks on speech act theory. Speech Act Theory and Pragmatics, Holland, pp. 291-312.

4. Ballmer Th., Brennenstuhl W. (1981) Speech Act Classification. Berlin : Mouton de Gruyter.

5. Arutjunova N.D. (1976) Predlozhenie i ego smysl. Logiko-semanticheskie problemy [Sentence and its meaning. Logical and semantic problems]. Moscow : Nauka [in Russian].

6. Vozijanova N.V. (1991) Semanticheskaja struktura i tekstovye funkcii glagolov rechi [Semantic structure and textual functions of speech verbs] (PhD Thesis), Moscow : Moscow State Linguistic University.

7. Gol'din V.E. (1983) Rech' i jetiket [Speech and etiquette]. Moscow : Prosveshchenie [in Russian].

8. Dem'jankov V.Z. (1982) Anglo-russkie terminy po prikladnoj lingvistike i avtomaticheskoj pererabotke teksta [English-Russian terms in applied linguistics and text automatic processing].
Tetradi novyh terminov, vol. 39, pp. 159-195 [in Russian].

9. Zhumagulova B.S. (1987) Kategorija kontaktnosti mezhdu partnerami kommunikacii [Contrast category between partners of communication] (PhD Thesis), Moscow : Moscow State Linguistic University [in Russian].

10. Karasik V.I. (2002) Jazyk social'nogo statusa [The social status language]. Moscow : ITDGK, «Gnozis» [in Russian].

11. Larina T.V. (2009) Kategorija vezhlivosti i stil' kommunikacii. Sopostavlenie anglijskih i russkih lingvokul'turnyh tradicij [Politeness category and communication style. Comparison of English and Russian linguo-cultural traditions]. Moscow : Rukopisnye pamyatniki Drevney Rusi [in Russian].

12. Romanov A.A. (1984) Pragmaticheskie osobennosti performativnyh vyskazyvanij [Pragmatic peculiarities of performative utterances]. Pragmatika $i$ semantika sintaksicheskih edinic, pp. 86-92 [in Russian].

13. Adamakova Je.B. (2005) Semantiko-pragmaticheskie svojstva i konteksty funkcionirovanija sredstv vyrazhenija blagodarnosti $\mathrm{v}$ nemeckom jazyke [Semantic and pragmatic properties and contexts of gratitude lingual means functioning in German] (PhD Thesis), Pyatigorsk : Pyatigorsk State Linguistic University [in Russian].

14. Tjagunova Zh.A. (2002) Konteksty funkcionirovanija i semantika vyrazhenij Thank you i Thanks (kognitivno-pragmaticheskij podhod) [Contexts of functioning and semantics of Thank you and Thanks utterances (cognitive-pragmatic approach)] (PhD Thesis), Pyatigorsk : Pyatigorsk State Linguistic University [in Russian].

15. Skovorodina S.V. (2004) Pragmatika reaktivnyh rechevyh aktov $\mathrm{v}$ nemeckom dialogicheskom diskurse (koncepty «blagodarnost'» $\mathrm{i}$ «izvinenie») [Pragmatics of responding speech acts in German dialogical discourse (gratitude and apology concepts)] (PhD Thesis), Saint Petersburg : Herzen University [in Russian].

16. BrownP.,LevinsonS.(1987)Politeness:Universals in Language Usage. Cambridge : Cambridge University Press.

17. Trofimova N.A. (2011) Ot ljubvi do nenavisti. Smyslovye uzory jekspressivov [From love to hatred. Semantic patterns of expressives]. Saint Petersburg : IVESEP [in Russian].

18. Curikova L.V. (2008) Diskursivnoe sobytie vyrazhenija blagodarnosti v anglijskom i russkom jazykah [Discourse event of expressing gratitude in English and Russian]. Kalbu Studijos: Studies about Languages, vol. 13, pp. 60-70.

19. Aijmer K. (1996) Conversational Routines in English: Convention and Creativity. London : Longman Group. 
20. Kuharenko V.A. (2019) Interpretacija teksta [Text interpretation]. Moscow : FLINTA [in Russian].

21. Chumakov G.M. (1972) Sistema vvodov prjamoj rechi, ih funkcii i stilisticheskoe ispol'zovanie [System of direct speech introductions, their functions and stylistic usage]. Nauchnye doklady vysshej shkoly. Filologicheskie nauki, vol. 2, pp. 76-88.

22. Voronin A.A. (2004) Informativnyj potencial avtorskih vvodov konstrukcij prjamoj rechi (na materiale romanov Dzh. Golsuorsi) [Informative potential of author's introductions of direct speech constructions (on the material of J. Galsworthy's novels)] (PhD Thesis), Moscow : Moscow State Linguistic University [in Russian].

23. Shhelkunova O.V. (2009) Funkcionirovanie sredstv nominacii zritel'nogo vosprijatija v avtorskom kommentarii (na materiale russkogo i anglijskogo jazykov) [Functioning of devices nominating vision perception in author's commentary (on the material of Russian and English)], (PhD Thesis), Oryol : Oryol State University [in Russian].

24. Ozhegov S.I. (1984) Slovar' russkogo jazyka [Russian Dictionary] / pod red. N.Ju. Shvedovoj. Moscow : Russkiy yazyk [in Russian].

25. Selivanova E.A. (2002) Osnovy lingvisticheskoj teorii teksta i kommunikacii [Fundamentals of linguistic theory of text and communication]. Kiev : TsUL, «Fitosotsiotsentr» [in Russian].

26. Selivanova O.O. (2006) Suchasna linhvistyka. Terminolohichna entsyklopediia [Modern linguistics. Terminology encyclopaedia]. Poltava : Dovkillja-K. [in Ukrainian]
27. Kivenko I.O. (2018) Movlennievyi akt podiaky : prahmalinhvistychnyi analiz (na materiali anhliiskoi movy) [Gratitude speech act: pragmatic and linguistic analysis (based on the material of the English language)] ( $\mathrm{PhD}$ Thesis), Odessa : Odessa I.I. Mechnikov National University [in Ukrainian].

28. Kivenko I.O. (2013) Rivnevi kharakterystyky MA vdiachnosti v anhlomovnomu khudozhnomu dyskursi [Level characteristics of gratitude speech act in English artistic discourse]. Naukovyi visnyk Khersonskoho derzhavnoho universytetu. Seriia «Linhvistyka», vol. 19, pp. 156-159 [in Ukrainian].

29. Ishiguro K. (2005) Never Let Me Go. London : Faber and Faber.

30. James E.L. (2012) Fifty Shades Darker. London : Arrow Books.

31. Williams P. (2010) How to be Married. London : Headline Publishing Group.

32. Fowles J. (2005) The French Lieutenant's Woman. London : Vintage.

33. Kinsella S. (2002) Shopaholic Ties the Knot. London : Black Swan.

34. Kinsella S. (2004) Shopaholic and Sister. London : Black Swan.

35. Sparks N. (2007) The Notebook. London : Sphere.

36. James E.L. (2012) Fifty Shades of Grey. London : Arrow Books.

37. Parsons T. (1999) Man and Boy. London : Harper Collins Publishers.

38. Bradford B. T. (2011) Playing the Game. London : Harper.

39. Weisberger L. (2013) Revenge Wears Prada: The Devil Returns. London : Harper. 